\title{
The Use of Smart Elements for the Transport Operation in the Slovak Cities
}

\author{
Oliver Bubelíny $^{1}$, Irina Ďad’ová ${ }^{1}$, Milan Kubina ${ }^{1}$ and Jakub Soviar ${ }^{1}$ \\ ${ }^{1}$ University of Žilina, Department of Management Theories, Univerzitná 8215/1, Žilina, Slovak \\ Republic;Email: oliver.bubeliny@fri.uniza.sk,irina.dadova@fri.uniza.sk, \\ milan.kubina@fri.uniza.sk, jakub.soviar@fri.uniza.sk
}

*Corresponding Author: Oliver Bubelíny

\begin{abstract}
The possibilities of expanding the transport infrastructure in cities are considerably limited, as urban areas of the municipalities are built-up. The current infrastructure is no longer sufficient to meet standard transport needs in cities, as there has been a growing trend in recent years for both manufactured and sold vehicles. The reason that vehicles are manufactured is the high demand for the purchase of these vehicles, which clearly reflects the subsequent trend of the traveling public using individual transport modes. In individual chapters, this article evaluates the simultaneous use of intelligent transport systems in the Slovak cities and, at the same time, points out further possibilities of SMART elements implementation in transport, which can ensure more efficient transport processes in agglomerations. Given the circumstances that transport infrastructure is no longer sufficient and the vehicles are stationary, which has adverse effects on arrival time as well as on the environment and the quality of life in the cities, the manuscript deals with this issue in particular.
\end{abstract}

Keywords: Transport operation, intelligent transport systems, smart transportation, Unmanned Aerial Vehicle

\section{Introduction}

The increase in traffic currently also means an increase in the number of means of transport on the roads. However, the built infrastructure ceases to be sufficient for this trend, and in this context, traffic jams arise which slows down the movement of people and goods to their destination. In 2015, 1.1 billion cars and almost 400 million trucks were driven worldwide. In 2040, it is estimated that 2 billion cars and 800 million trucks will be driven around the world [1]. The present time offers space for the use of ICT elements that can effectively collect, transmit, process, store, secure and present the required information for the needs of the business company [2]. 
These functions are not only valid in relation to business information systems, but also to information systems that are used for traffic management in cities. These are sensors that are installed directly in traffic and can provide real-time traffic information. Sensors provide information primarily to control (dispatching) centers, where they are subsequently evaluated and used to support decision-making. Conversely, information is also provided to vehicle drivers in traffic, which is provided by light (digital) signs with variable character. Drivers can get more information from navigation or radio. As the development of technologies continues to progress among other elements, it is possible to include the Unmanned Aerial Vehicle (hereinafter as UAV) platform, cooperative navigation $[3,4]$.

\section{Methodology}

To prepare this research study, it was necessary to create a basic overview of the selected literature in a given topic. It includes mainly an explanation of basic terms in transport - transport, mobility. For processing this part of the article the method of analysis of documents from primary sources was used. These were mainly printed publications focused on this issue. The parts focused on the description of the current situation in Slovakia and other possibilities of using smart elements in cities were processed on the basis of the analysis of documents from primary sources, which supplemented secondary sources mainly in the form of articles on intelligent transport in Slovakia.

The criterion for suitability of the appropriateness of the article was mainly the year of publication, which could not be older than 2014, as progress in information technology is extremely rapid. The induction was used to form the conclusions.

\section{Literature Review}

Transport is an organized activity which purpose is to move tangible objects or people from the initial to the final location using means of transport and technology with regard to spatial and temporal aspects. In general, it can be claimed that it is a service that satisfies transport needs, whether in terms of freight or passengers transport. Standard STN 018500 defines transport as "deliberate movement of means of transport along transport routes or the activity of transport facilities carrying out transport". Nowadays, it is more common to use the expression mobility which is broader than transport and it represents the movement of goods and services by means of transport, as formulated for example in literatures [5,6]. Mobility as such is an approach to get people to the selected places safely, at the right time, at an appropriate price level (schools, work, hospitals, etc.). It does not take into account the means of transport used. 
The commencement of the INDUSTRY 4.0 era has made a space for using ICT for intelligent traffic management and to building smart cities over time. According to the European Union and particular scientific publications [7-9], it is a concept that combines several components: the use of information technology, efficient transport, sustainable energy consumption and a clean environment. From this point of view, it will be possible to manage urban transport more efficiently, avoiding traffic jams. ICT in transport is a multimodal tool that combines advanced technologies and applies them to transport to improve transport quality. ICT in transport is covered by the separate scientific branch - transport telematics [10-13].

This field of study integrates telecommunications, information and automation and control technologies in order to increase the transport performance of existing infrastructure. Since road transport is experiencing a sharp increase and the continuous expansion of urban infrastructure it is not possible mainly from a technical point of view, so right the optimization of ICT traffic is a solution. Table 1 shows the basic ICT technologies in terms of data processing [1].

Table 1 ICT technologies in terms of data processing. Source: [1]

\begin{tabular}{ccc}
\hline & \multicolumn{1}{c}{$\begin{array}{c}\text { Technical equipment in } \\
\text { communications }\end{array}$} & Devices in vehicles \\
\hline \multirow{2}{*}{ data collection } & traffic detectors & vehicle identification \\
\cline { 2 - 3 } data processing & weather monitoring & dynamic weighing \\
\cline { 2 - 3 } data transfer & data in controllers & position system \\
\cline { 2 - 3 } & eptical transmission of information & dedicated communication \\
\hline redistribution of & firm communication & radio channel, navigation \\
\cline { 2 - 3 } information & variable traffic brands & transport service \\
\hline \multirow{2}{*}{ use of information } & internet & vehicles guidance \\
\cline { 2 - 3 } & traffic management & prevention of accident \\
\hline
\end{tabular}

\section{Current Situation of Managing Transportation Processes in Slovakia}

In Slovakia, cities are gradually introducing intelligent traffic management, which is an important tool for traffic management and regulation. The application of this instrument under the conditions of the Slovak Republic is as follows:

- implementation of a camera and surveillance system that monitors the real situation at selected crossroads and subsequently the situation evaluated by a computer, 
- the introduction of variable road signs that can inform drivers in good time of traffic, accidents and offer diversions.

Intelligent transport systems in transport in Slovakia are also defined by Act no. 317/2012 Coll., which regulates the framework of introduction and their subsequent use. Intelligent transport information system itself defines as "information and communication technology or in-vehicle system, which is used to optimize road traffic, mobility management, increase road safety and fluidity, streamline road management and maintenance, improve public transport services and reduce environmental burden which is also used for interfaces with other modes of transport". As such, the Act also regulates the operators of these systems. Under the conditions of the Slovak Republic, these are mostly cities, in the case of motorways, the National Motorway Company, which monitors motorway sections [14].

Intelligent systems in transport in Slovakia are also defined by Act no. 317/2012 Coll., which regulates the framework of introduction and their subsequent use. Intelligent transport information system itself is defined as "information and communication technology or in-vehicle system, which is used to optimize road traffic, mobility management, increase road safety and fluidity, streamline road management and maintenance, improve public transport services and reduce the environmental burden which is also used for interfaces with other types of transport". Under the conditions of the Slovak Republic these are mostly cities, in the case of motorways it is the National Motorway Company, which monitors sections of motorways [14].

Since 2017, the National Traffic Information Center has been operating in Slovakia. Its task is mainly to collect, evaluate and subsequently provide traffic information to the general public. Various authorities contribute to this center with information that directly affects traffic. According to Act no. 317/2012 Coll. these are [14]:

- Police force;

- Coordination Center of Integrated Rescue System;

- State administration authorities for land communications;

- Owner and administrator of the roads;

- Toll collection management;

- The Slovak Hydrometeorological Institute;

- Customs Office and Financial Directorate of the Slovak Republic;

- Radio and Television of Slovakia;

- Owner and administrator of utilities that can affect road safety and fluency;

- Service Provider;

- Carrier; 
In addition to solutions at the state level, solutions at the level of higher territorial units and municipalities are also used. These are primarily smart junctions. These are intersections that can autonomously evaluate the traffic situation over time. The control unit evaluates data from sensors that are located in front of the intersection, or from GPS or digital maps. Other sensors are located directly at the intersection. These are sensors that can sense the number of vehicles as well as their current speed. Among other things, they follow pedestrians who need to get to the other side of the road. Such intersections can, if necessary, prefer incoming public transport vehicles over other vehicles. The advantage of such intersections is the acceleration of traffic, as the signals are adjusted according to the current traffic situation. These types are also connected to monitoring centers, which can remotely control the intersection if necessary $[6,15,16]$.

\section{Results and Discussion - Possibilities of Using SMART Elements}

At present, intelligent transport systems in the Slovak and foreign cities are built on the basis of cameras and sensors, which evaluate the traffic intensity. It can be claimed that these systems are functioning properly, but they cannot cover the entire area of interest. In the case that this situation should occur, it would be necessary to install a large number of additional cameras and sensors in order to evaluate the situation in space. Spatial evaluation can be understood as evaluating the trajectory of a vehicle at a junction or node. In most cases, sensors and cameras only capture the vehicle's entrance, but not the entire monitored area $[3,17]$.

\subsection{Application of UAV Platform for Traffic Monitoring}

Right here, it comes to sight a possibility of applying UAV for traffic monitoring, managing and controlling, because it can cover whole intersection area (as well as parking places, roads, nodes and others). UAV platform can collect data about an amount of the vehicles that cross selected points as well as spots where the vehicles leave or else about the roads that are heavily loaded.

Nowadays, UAVs are considered to be one of the most dynamic and multidimensional technologies in the world. Drones as technology are gradually deployed in several parts of life. From commercial use, for example, they are deployed to delivery packages.

The advantage of using UAV platform in transport processes is low cost and high possibility of displaying data on large area. Lower costs are also caused by the possibility of moving the device to another location. Due to the coverage of a large area there is also the accuracy of the obtained data, which is then subjected to analysis. There are also several disadvantages to using the UAV platform.

There are also several disadvantages to using the UAV platform. The battery life of the drones is relatively low and therefore traffic monitoring is only possible for a certain period of time and 
then the device must land. Another disadvantage is the weather effects which can significantly affect the quality of the data. With the increasing number of UAVs, several legislative measures have been introduced to regulate the use of these devices. Improper use of these devices in transport could have fatal consequences. Advantages and disadvantages of using drones in transport are compared in Tab. 2 [17].

Table 2 Advantages and disadvantages of using drones. Source: [17]

\begin{tabular}{cl}
\hline Advantages & Disadvantages \\
\hline Low cost & Low range time \\
\hline Large coverage of the monitoring area & Weather effects \\
\hline Flexibility & Legislative restrictions \\
\hline Accuracy of the obtained data & \\
\hline
\end{tabular}

From the research conducted so far, a basic framework has been created, which makes recommendations for the monitoring of transport processes using the UAV platform. These are 6 basic activities, which are divided into two basic parts, namely the part where the drone monitoring is performed directly and the part where the software support is used for data analysis and subsequent optimization.

The mentioned frame is depicted in Fig. 1. The start of the process itself is conditioned by the selection of the monitoring equipment according to the available parameters of the monitored part.

The following activities must be carried out in the UAV section $[17,18]$ :

- Flight planning where safety, route and environment need to be taken into account;

- Taking a flight with an emphasis on the quality of the recorded video;

- - Obtaining data that can be obtained in real time or offline after the flight itself;

- After data collecting, it is possible to access the software part where:

- Managing and analyzing obtained data from the UAV platform is a relatively new topic where the analysis itself is performed using different algorithms;

- Data interpretation depends on the scope of the whole framework (all road users, or only selected participants);

- Optimization is the result of the whole monitoring (lane adjustment, setting of the light signaling, etc.). 


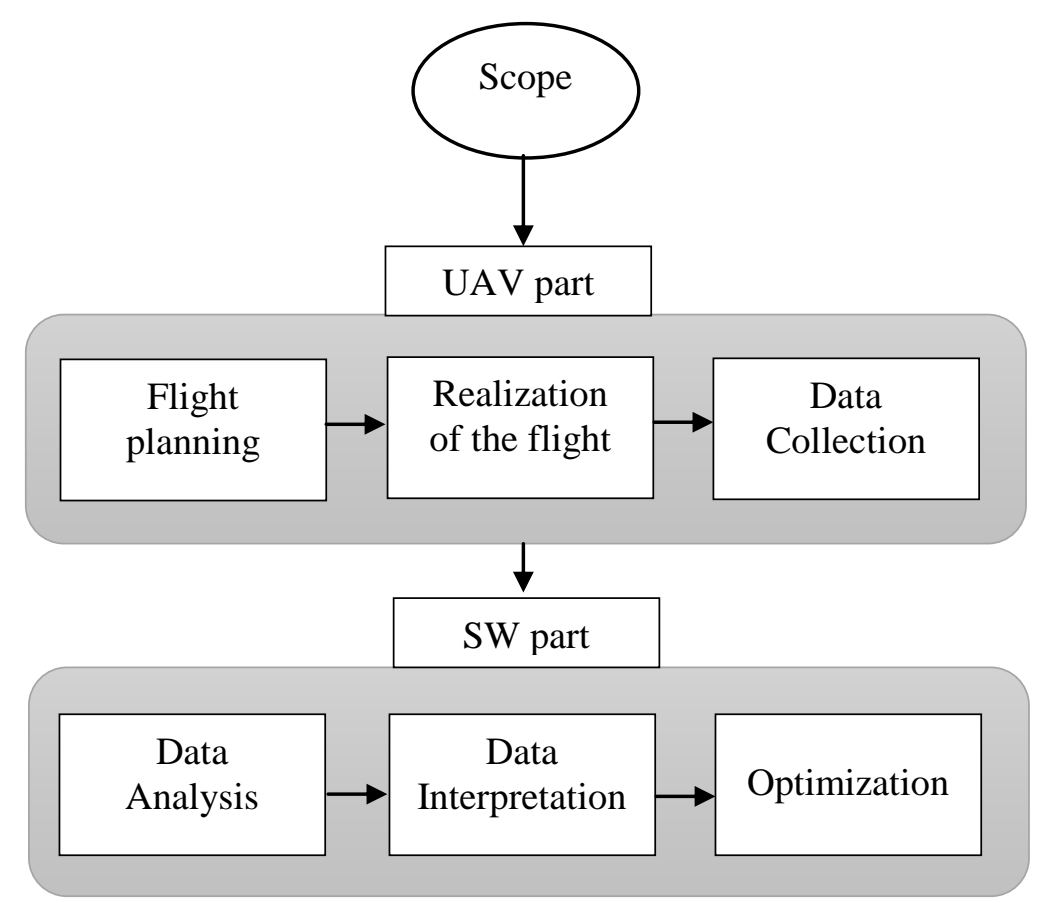

Fig. 1 The basic framework for transport monitoring using UAV. Source: [17]

\subsection{Use of Sensors in Vehicles}

Today's navigation systems use the Internet in addition to the GPS signal. The main advantage of these systems is the fact that drivers can inform each other about the danger on the road (traffic accident, dangerous situation due to natural conditions, etc.), or they can provide information about the police patrol. Navigation, thanks to the signal emitted from the mobile phone, can transmit data that is analyzed and evaluated, and then can help other drivers plan the route. This type of navigation is provided by several providers (WaZe, Google maps). They are not directly tied to the vehicle, only to the device where navigation is installed. The implementation of these technologies directly into vehicles is currently in progress [19].

Modern vehicles have sensors that can identify obstacles when parking a vehicle. They can also brake autonomously safely against an obstacle in the path (e.g. pedestrian). Sensors are also used to secure proper spacing between vehicles. Another function of vehicles is reading road signs and set the desired speed. In addition to these sensors, there are others that can communicate with other vehicles or transmit and retrieve information from the national traffic information center. The vehicle becomes intelligent if it can communicate with its surroundings by means of its technological equipment (other vehicles, control centers, etc.). Basic benefits of smart cars in cities include [20-22]:

- Sharing information between other vehicles that can exchange information about condition of the road, or the current traffic situation on the desired section;

- Distribution of information from control center about temporary closures etc. 
- Some degree of autonomy in driving a vehicle, which means that the vehicle can take control of the vehicle for a certain period of time, or stop it in an emergency;

- Saving vehicle fuel by efficient route layout to the final destination and time savings from efficient route layout;

- Improving the urban environment by minimizing traffic jams in the cities.

It is necessary to include higher purchase prices to the main disadvantage of intelligent vehicles as well as possibilities of system failure that could bring fatal consequences mainly in case that driver absolutely relies on the system. It is also important to put the impact on the topic of data security [23].

\section{Conclusion}

The use of smart elements in transport is the future. While nowadays, there is no ability to expand urban infrastructure and socio-economic development mainly helps individual transport, it is essential to look for alternatives that will allow travelers to reach their destination in time and eliminate the environmental impact of urban transport.

Right there, it comes into sight some space for use of smart intersections, the UAV platform for monitoring the current traffic situation, and the use of intelligent vehicles equipped with sensors and cooperative navigation, taking into account the current traffic situation and the behavior of other drivers in towns. Last but not least, it should be pointed out that the use of smart cars is also tied to the gradual construction of smart places. Only then, cities can achieve the synergy effect of building a smart company.

\section{Acknowledgments}

This publication was realized with support of the Operational Program Research and Innovation in frame of the project: ICT for smart society, code ITMS2014 +: 313011T462, co-financed by the European Regional Development Fund.

\section{References}

[1] Schlosser, T. (2001). Inteligentné dopravné systémy. Bratislava: Jaga group. ISBN 80-8890564-8. (in Slovak)

[2] Fortunati, J. (2018). Mobility Lab. Mobility doesn't mean the same thing as transportation. Retrieved August 29, 2019, from https://mobilitylab.org/2018/07/26/what-is-mobility/. 
[3] Furik, A. \& Szalai, P. (2017). Smart cities: Budúcnost' miest v Európe. (2017). Retrieved August 30, 2019, from https://euractiv.sk/section/digitalizacia/linksdossier/smart-citiesbuducnost-miest-v-europe/. (in Slovak)

[4] The number of cars worldwide is set to double by 2040. (2016). Retrieved September 02, 2019, from https://www.weforum.org/agenda/2016/04/the-number-of-cars-worldwide-is-setto-double-by-2040.

[5] Ptošek, V., Ševčík, J., Martinovič, J., Slaninová, K., Rapant, L. \& Cmar, R. (2018). Real time traffic simulator for self-adaptive navigation system validation. In 30th European Modeling and Simulation Symposium, EMSS 2018, 274-283.

[6] STN 01 8500. Slovak Technical Standard. Základné názvoslovie v doprave. 2000. (in Slovak)

[7] Skrúcaný T., Kendra M., Stopka O., Milojević S., Figlus T. \& Csiszár C. (2019) Impact of the Electric Mobility Implementation on the Greenhouse Gases Production in Central European Countries. Sustainability. 11(18), Article no. 4948. DOI: 10.3390/su11184948.

[8] Szumska, E., Pawełczyk, M. \& Pistek, V. (2019). Evaluation of the Life Cycle Costs for urban buses equipped with conventional and hybrid drive trains. The Archives of Automotive Engineering - Archiwum Motoryzacji. 83(1), 73-86. DOI: 10.14669/AM.VOL83.ART5.

[9] Lucietti, L., Hoogendoorn, C. \& Cré, I. (2016). New tools and strategies for design and operation of urban transport interchanges. Transportation Research Procedia. 14, 1240-1249. DOI: 10.1016/j.trpro.2016.05.195.

[10] Mańkowski, C. \& Weiland, D. (2018). Logistics of information in intermodal transport. MATEC Web of Conferences 235, In 10th International Scientific Conference Horizons of Railway Transport. 11-12 October 2018, Strecno, Slovakia. DOI: 10.1051/matecconf/201823500013.

[11] Sărăcin, A., Coșarcă, C., Savu, A., Negrilă, A.F.C. \& Didulescu, C. (2018). Telematics and intelligent transport. In International Multidisciplinary Scientific GeoConference Surveying Geology and Mining Ecology Management - SGEM 18(2.2). 2-8 July 2018 (pp. 427-434). Albena, Bulgaria. DOI: 10.5593/sgem2018/2.2/S08.054.

[12] Hopkins, J. \& Hawking, P. (2018). Big data analytics and IoT in logistics: A case study. International Journal of Logistics Management. 29(2), 575-591. DOI: 10.1108/IJLM-05-20170109.

[13] Kubasakova, I., Kampf, R. \& Stopka, O. (2014). Logistics information and communication technology. Communications - Scientific Letters of the University of Zilina. 16(2), 9-13. 
[14] Zákon pre l'udí.sk. Website. Zákon č. 317/2012 Z. z. Zákon o inteligentných dopravných systémoch $v$ cestnej deprave. Retrieved October 10, 2019, from https://www.zakonypreludi.sk/zz/2012-317. (in Slovak)

[15] Hladký, V. \& Muchová, M. (2014). Návrh a simulácia roadenie vybranej križovatky. Transfer inovácií. ISSN 1337-7094. Retrieved October 10, 2019, from https://www.sjf.tuke.sk/transferinovacii/pages/archiv/transfer/29-2014/pdf/267-272.pdf.

[16] Trenčín testuje prvú inteligentnú križovatku. (2019). Retrieved October 11, 2019, from https://w5.siemens.com/web/sk/sk/aktuality_a_temy/tlacovespravy/mesta_infrastruktura/pages/trencin_inteligentna_krizovatka.aspx.

[17] Khan, M.A., Ectors, W., Bellemans, T., Janssens, D. \& Wets, G. (2017). UAV-Based Traffic Analysis: A Universal Guiding Framework Based on Literature Survey. Transportation Research Procedia. 22, 541-550.

[18] Mualla, Y., Najjar, A., Daoud, A., Galland, S., Nicolle, C., Yasar, A.U.H. \& Shakshuki, E. (2019). Agent-based simulation of unmanned aerial vehicles in civilian applications: A systematic literature review and research directions. Future Generation Computer Systems. 100, 344-364. DOI: 10.1016/j.future.2019.04.051.

[19] Hu, L., Liu, A., Xie, M. \& Wang, T. (2019). UAVs joint vehicles as data mules for fast codes dissemination for edge networking in smart city. Peer-to-Peer Networking and Applications. 12(6), 1550-1574. DOI: 10.1007/s12083-019-00752-0.

[20] Hittmár, Š, Lendel, V. \& Kubina, M. (2013). Podnikové informačné systémy: teoretické a praktické otázky tvorby a uplatňovania informačných systémov v podniku, 1. vyd., Žilina: University of Žilina, Slovak Republic, 228 p. ISBN 978-80-554-0712-8.7. (in Slovak)

[21] Program podpory rozvoja inteligentných dopravných systémov. Národný systém dopravných informácií. Retrieved October 10, 2019, from https://www.mindop.sk/ministerstvo-1/doprava3/strategia/program-podpory-ids-nsdi/vlastny-material-pdf. (in Slovak)

[22] Salvo, G., Caruso, L., Scordo, A., Guido, G. \& Vitale, A. (2017). Traffic data acquirement by unmanned aerial vehicle. European Journal of Remote Sensing. 50(1), 343-351. DOI: 10.1080/22797254.2017.1328978.

[23] Belhajem, I., Ben Maissa, Y. \& Tamtaoui, A. (2016). A robust low cost approach for real time car positioning in a smart city using Extended Kalman Filter and evolutionary machine learning. In Colloquium in Information Science and Technology - CIST2016. 24-26 October 2016 (pp. 806-811). Tangier-Assilah. Morocco. DOI: 10.1109/CIST.2016.7804998. 